\title{
Using Chemical Modeling to Asses Water Quality in the Raigón Aquifer System in Southern Uruguay
}

\author{
Julia Torres ${ }^{1, *}$, Lorena Gonzatto ${ }^{1}$, César Goso ${ }^{2}$, José Luis Fernández-Turiel ${ }^{3}$, Marta Rejas ${ }^{3}$, Maite García-Vallés ${ }^{4}$, \\ Carlos Kremer ${ }^{1}$, Eduardo Kremer ${ }^{1}$ \\ ${ }^{1}$ Cátedra de Química Inorgánica, DEC, Facultad de Química, Montevideo, Uruguay \\ ${ }^{2}$ Instituto de Ciencias Geológicas, Facultad de Ciencias, Montevideo, Uruguay \\ ${ }^{3}$ Instituto de Ciencias de la Tierra Jaume Almera, labGEOTOP, CSIC, Barcelona, España \\ ${ }^{4}$ Facultat de Geologia, Universitat de Barcelona \\ *Corresponding author: jtorres@fq.edu.uy
}

Received April 29, 2015; Revised May 19, 2015; Accepted May 26, 2015

\begin{abstract}
The Raigón aquifer is an important groundwater system in southern Uruguay. The increasing use of groundwater resources in the last decades has provoked changes in the concentration of many elements which are strongly related to anthropogenic pollution sources. Concentration levels are useful to detect changes in reservoir status but it is also necessary to analyze their chemical significance in order to make an accurate assessment of the sources of contamination and the causes of changes. In this work we use the available thermodynamic data to calculate chemical speciation on these groundwater samples. Trace elements present as anions, in particular Se and Mo, are especially focused to show the chemical modeling possibilities. Both elements form anionic species, predominantly $\mathrm{MoO}_{4}{ }^{2-}$ and $\mathrm{SeO}_{4}{ }^{2-}$. Results show that these anions interact in solution and are greatly influenced by the concentration of the abundant calcium ion. Localized changes in $\mathrm{pH}$ can strongly affect the situation. The same is observed with the $\mathrm{p} E$ parameter, but only in the case of Se. Chemical speciation of trace elements is in general highly dependent on $\mathrm{pH}, \mathrm{pE}$ and concentration of major elements. In consequence, for a fixed analytical total concentration, these parameters can markedly change the situation, affecting the mobility, the bioavailability and environmental fate of these elements. The strategy employed in this work can also be extended to the study of many other environmental water scenarios.
\end{abstract}

Keywords: Raigón aquifer system, groundwater, chemical modeling, speciation, trace elements

Cite This Article: Julia Torres, Lorena Gonzatto, César Goso, José Luis Fernández-Turiel, Marta Rejas, Maite García-Vallés, Carlos Kremer, and Eduardo Kremer, "Using Chemical Modeling to Asses Water Quality in the Raigón Aquifer System in Southern Uruguay.” Journal of Environment Pollution and Human Health, vol. 3, no. 2 (2015): 31-38. doi: 10.12691/jephh-3-2-2.

\section{Introduction}

The Raigón aquifer system is one of the most important groundwater systems in southern Uruguay, constituting a site of environmental interest. It extends over 2,200 $\mathrm{km}^{2}$ in the Mesozoic Santa Lucía basin (Figure 1). The Raigón formation [1] shows stratified yellowish coarse ortoconglomerates, polimict gravel and calcareous cement. White yellowish coarse to fine sands, wackes and green lenticular mud are interbeded. Channel filled, sand barriers and even tabular flood-plain and front deltaic deposits are the most common facies observed in this area. The Pliocene stratigraphic sequence reaches 40 to 50 meters thickness $[2,3]$. Adjacent wetlands contribute to the slow recharge of this aquifer system which shows unconfined, semiconfined and confined behavior as well as multilayer type characteristics; chemical analysis shows that the Raigón aquifer groundwater can be classified as sodium bicarbonate type [2].

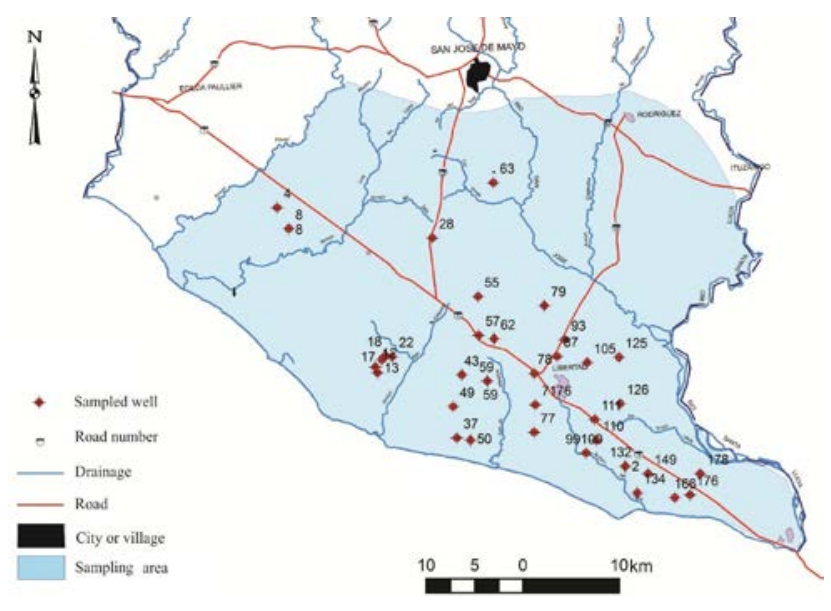

Figure 1. Localization of groundwater sampling points in southern San José department

In Uruguay, domestic (in urban areas) and agricultural demands are nowadays mainly satisfied by surface water. However, the use of groundwater resources has experienced a fast increase since the 1950s. This is mostly 
due to growth of dairy farm activities, supported by water wells [2]. Being an important groundwater reservoir, the Raigón aquifer water quality is monitored through different analytical parameters.

The analytical measurement of the concentration of the elements in natural water systems is the primary tool used to monitor the water environmental status. This allows checking that concentration levels do not exceed the maximum recommended thresholds.

As a consequence of the processes of aging caused by different natural chemicals (e.g. dioxygen, carbon dioxide, water) the abundance, dispersion and chemical forms of the various elements in these groundwater reservoirs change over time [4]. The concentration of each element in the aquatic system is a result of a mass balance between its input and output from the system. A very slow accumulation of elements in groundwater is expected and the presence of the biosphere enhances these changes [5], [6]. Furthermore, human activities on the ecosystem also affect the element status. Compared with natural processes, anthropogenic sources of elements usually produce faster changes in their baseline concentration levels.

Water quality sampling carried out in numerous locations in Latin America clearly shows also these changes [7]. A previous study has shown that in the main aquifers of south-western Uruguay, the occurrence and levels of some trace elements exceed the maximum values according to Uruguayan regulations and WHO recommendations showing both lateral and vertical variations in their concentrations [2]. Changes in the concentration of elements strongly related to anthropogenic pollution sources have been confirmed in the Raigón aquifer system in the last decade. For example, phosphorous concentrations in almost every sample exceed $25 \mu \mathrm{g} / \mathrm{L}$, the maximum threshold recommended by the regulations for water uses $[2,8]$. The aquifer system is also susceptible to contamination, mainly by nitrate and pesticides, such as atrazine, due to increasing agricultural activities in the area [9].

In natural waters, chemical elements are found in a wide range of concentration. Trace elements are arbitrarily defined as those with low natural abundance (of the order of $1 \mathrm{mg} / \mathrm{L}$ or less) in different environmental matrices $[10,11]$. In the last fifty years, the income of trace elements into the environment increased, mainly as a consequence of growing human activities. Due to their low abundance, even small changes in the input or output of elements may produce a significant impact on the concentration levels of these elements. The exploitation of raw materials mobilizes elements present as ores as well as impurities in the processed minerals, which are transformed into point sources of pollution. Besides, the small inputs of trace elements that are routinely used in agricultural activities can also affect the natural concentration levels by means of irrigation, fertilizers, soil and water amendments, animal manures, sewage effluents and sludge, and pesticides. Supplementation to correct deficiencies in the intake of essential elements for cattle (copper, selenium, molybdenum, zinc, iron, etc.) is also a diffuse source of income to aquatic environments and its impact on human health, agriculture and the environment has received increasing attention from scientists from different areas [12,13,14].

Chemical speciation of the elements in natural waters plays a fundamental role in their biogeochemical cycles.
Transportation across the hydrological cycle is strongly influenced by their chemical behavior in aqueous solution, defining the mobility and solubility of their thermodynamically stable ionic species, and consequently their environmental fate. Mobile forms of elements in water, mostly determined by the charge of the predominant species, include various soluble forms and are subject to numerous competing reactions.

When studying major conservative elements behavior, it is not necessary in most cases to consider chemical speciation. Each element has the same predominant species in almost any natural aquatic scenario, and concentration data, charge and mass balances are the only required tools to perform analysis. This is not generally true for trace elements. The total concentration values and eventual accumulation of trace elements in groundwater are influenced by a number of factors, mostly controlled by their speciation and reactivity, which determine mobility and transport processes. In addition, many trace elements show more than one possible oxidation state. This feature and the oxygen concentration might also influence the chemical forms and in turn the environmental fate of the elements. So, analytical measurements of the total concentration data of elements might not be enough to understand their chemical behavior in aquatic systems in order to design adequate strategies for quality preservation or remediation actions. The knowledge of the predominant chemical species of each trace element helps to analyze the mobilization of pollutants and the design of degradation or immobilization procedures. Chemical modeling is a very useful tool to address these issues when speciation needs to be considered. This strategy has proved to be an appropriate approach to understand the trace element behavior in many natural environments [15-20].

From chemical modeling viewpoint, relevant thermodynamic data must be available in order to predict the predominant species for a given sample, once analytical total concentrations are known. Many chemical reactions involved in the trace elements behavior have been studied and the equilibrium constants have been determined. Within the group of trace elements, the knowledge of those predominant as cations in the natural waters (such as iron, copper, manganese, etc.) is relatively greater in comparison with elements forming anionic species (e.g., selenium, molybdenum and tungsten) [21,22]. Some years ago, our group has started to study the interactions of elements forming anionic species under the conditions of the natural waters $[23,24,25]$. These data are the basis for the chemical model needed to assess the current status and the pollution trends in natural waters. In this work we show the use of chemical modeling applying these recent data to study the groundwater samples of the Raigón aquifer system in southern Uruguay.

Moreover, speciation of some elements in hypothetical scenarios is considered to study possible localized changes of certain physicochemical parameters. The strategy employed in this work can also be extended to the study of many other environmental water scenarios.

\section{Experimental}

Chemical composition data of thirty two water wells of the Raigón aquifer system were employed (data partially 
reported in [8]). In the collected samples, all elements with concentrations above their detection limits were included to perform calculations. The $\mathrm{pH}$, electrical conductivity and temperature values, determined in the field were taken from [8]. Samples were not filtered before performing chemical analyses. Concentration measurements were carried out by inductively coupled plasma-optical emission spectrometry (ICP-OES) and inductively coupled plasma-mass spectrometry (ICP-MS) [8]. Reported stability constants were employed to generate the chemical model using Visual MINTEQ software [26]. This software contains data compiled from the NIST Critical Stability constants database. The thermodynamic database included in this program was complemented with recently reported data under low ionic strength, measured at $20.0^{\circ} \mathrm{C}[23,24,25]$. Besides, two physicochemical parameters were also included as input data: $\mathrm{pH}$ and temperature. The $\mathrm{p} E$ value, calculated for oxygen saturation conditions at neutral $\mathrm{pH}$ was also generally used. Visual MINTEQ software describes the chemical system taking into account all known chemical species simultaneously. It calculates all the equilibrium concentrations of the chemical species, based on the stability constants included in its database by means of mass balances of the analytical concentrations of all the components provided. More than 300 species are individually considered in each calculation. For some samples, redox calculations were carried out and $\mathrm{p} E$ value was varied according to the depth of the sample. After mass balance calculations, every chemical species concentration is obtained as output. Speciation diagrams were produced by Hyperquad Speciation and Simulation (HySS) software [27]. HySS software is a system for providing speciation diagrams. The calculations relate to equilibria in solution and also include the possibility of formation of partially soluble precipitates.

\section{Results}

Table S1 includes all chemical data and physicochemical parameters for the 32 samples of the Raigón aquifer system used for calculation (locations shown in Figure 1). $\mathrm{pH}$ values vary from 6.35 to 7.48 (median value 7.11 ), temperature values are in the range 17.2 to 26.7 (median value $20.8^{\circ} \mathrm{C}$ ), and depth is between 4 and $45 \mathrm{~m}$ (median value $22 \mathrm{~m}$ ). Taking data on Table S1 as input, Visual MINTEQ program was employed to calculate the equilibrium concentration of every chemical species formed.

The median concentration values of $\mathrm{Na}, \mathrm{Ca}, \mathrm{Cl}, \mathrm{C}$ and $\mathrm{S}$ for the whole set of samples are in the range 5-100 mg/L. Minor and trace elements detected include those found as cations such as most alkali, alkaline-earth and $3 d$ transition metal ions, $\mathrm{Zn}, \mathrm{Cd}$ and $\mathrm{Pb}$, and some others currently encountered as anions: halides, B, P, V, Mo, As, Se and Sb. Some selected examples from Table S1 are shown in Table 1 . Sample 4 represents a typical sample: total concentration values, especially for the most abundant elements, are very similar to median values of all samples. Cationic elements such as $\mathrm{Ti}, \mathrm{Zr}$ or $\mathrm{U}$ are expected to form insoluble oxide/hydroxide forms under the oxidic conditions of these samples (median depth 22 $\mathrm{m})$. These compounds usually form colloidal dispersions and consequently they are excluded from the water environment. Since the samples were not filtered before the analytical determination of metal ions, total concentrations of elements bearing relatively high concentrations like iron (up to $0.4 \mathrm{mg} / \mathrm{L}$ ) or aluminum (up to $0.1 \mathrm{mg} / \mathrm{L}$ ) might also include a significant proportion of suspended solid oxide/hydroxide forms.

From data on Table S1, Visual MINTEQ program was employed to calculate the equilibrium concentration of every chemical species formed. Table S2 shows the results obtained for all speciation calculation, whereas Table 2 summarizes the most relevant data, indicating the predominant species of selected elements calculated for the equilibrium situation of all 32 samples using Visual MINTEQ software [26] complemented with recent data on trace elements [23,24,25]. Results show that major element concentrations are extremely important to define the chemical scenario.

\subsection{Speciation of the Most Abundant Elements}

According to the well-known chemical interactions at the $\mathrm{pH}$ interval found in these groundwater samples, (6.35-7.48), results summarized in Table 2 show that the predominant forms for the most abundant elements are the free cations $\mathrm{Na}^{+}, \mathrm{K}^{+}, \mathrm{Mg}^{2+}, \mathrm{Ca}^{2+}$, and the anions $\mathrm{Cl}^{-}, \mathrm{SO}_{4}{ }^{2-}$ and $\mathrm{HCO}_{3}{ }^{-}[4,21,22]$. In the case of S- and C-based anions, the speciation depends both on $\mathrm{pH}$ and $\mathrm{p} E$ of the samples [4]. Nevertheless, for oxygen saturated conditions around neutral $\mathrm{pH}$, sulfate and bicarbonate are always the most abundant species.

Table 1. Total analytical concentrations used for speciation calculations. pH values, temperature and depth are also included

\begin{tabular}{|c|c|c|c|c|}
\hline Sample ID & 4 & 111 & 125 & 57 \\
\hline \multicolumn{5}{|c|}{ Element concentrations - mg/L } \\
\hline $\mathrm{Na}$ & 90.49 & 277.86 & 85.33 & 273.29 \\
\hline $\mathrm{K}$ & 4.19 & 5.03 & 4.88 & 5.68 \\
\hline $\mathrm{Ca}$ & 50.20 & 122.11 & 29.32 & 90.37 \\
\hline Mg & 14.45 & 30.64 & 8.82 & 28.41 \\
\hline $\mathrm{Cl}$ & 18.19 & 334.58 & 48.46 & 257.39 \\
\hline S & 4.08 & 50.54 & 5.81 & 34.22 \\
\hline $\mathrm{C}$ & 83.73 & 98.96 & 51.60 & 113.9 \\
\hline \multicolumn{5}{|c|}{ Element concentrations x1000 - mg/L } \\
\hline $\mathrm{Sr}$ & 468.24 & 992.42 & 260.11 & 817.99 \\
\hline $\mathrm{Ba}$ & 184.77 & 94.29 & 94.35 & 103.18 \\
\hline $\mathrm{Mn}$ & 1.15 & 2.26 & 5.31 & 0.76 \\
\hline $\mathrm{Fe}$ & 7.97 & 63.90 & 46.55 & 11.49 \\
\hline Co & 0.14 & 0.17 & 0.06 & 0.12 \\
\hline $\mathrm{Ni}$ & 1.84 & 2.46 & 1.01 & 2.03 \\
\hline $\mathrm{Cu}$ & 1.10 & 2.23 & 0.69 & 2.85 \\
\hline $\mathrm{Zn}$ & 31.64 & 453.52 & 77.91 & 33.73 \\
\hline $\mathrm{Cd}$ & 0.11 & 0.03 & 0.02 & 0.04 \\
\hline $\mathrm{Pb}$ & 0.83 & 0.31 & 0.21 & 0.11 \\
\hline $\mathrm{P}$ & 6.51 & 5.24 & 153.04 & 3.01 \\
\hline Se & 2.43 & 2.43 & 0.52 & 1.50 \\
\hline Mo & 1.25 & 0.85 & 0.70 & 1.12 \\
\hline V & 41.28 & 35.67 & 25.96 & 45.71 \\
\hline As & 12.57 & 11.28 & 12.61 & 15.81 \\
\hline \multicolumn{5}{|c|}{ Physicochemical parameters } \\
\hline $\mathrm{pH}$ & 7.48 & 7.22 & 7.03 & 7.17 \\
\hline Depth/m & 33 & 19 & 6 & 45 \\
\hline Temperature $/{ }^{\circ} \mathrm{C}$ & 20.0 & 21.1 & 20.8 & 20.7 \\
\hline
\end{tabular}


As expected, alkali ions and halides remain as the +1 or -1 species in all studied samples (Table 2). Their speciation is also independent of other parameters as $\mathrm{pH}$, depth, water hardness, etc. Very similar values are obtained for the 32 studied samples (standard deviation calculated for alkali cations and halides percentages are lower than 0.3 ). Results show that -1 anions do not have a great influence on cation speciation (Table 2). In fact, almost all these associations are negligible in the presence of more charged anions [21,22]. Conversely, the interaction of +1 cations with various anions is in general also negligible [21,22], except for highly charged anions which are not present in these groundwater scenarios. So, major elements existing as +1 or -1 ionic species are not relevant in the whole interaction. Only for sea water, where the concentration of halides is extremely high, associations of some metal ions with chloride or bromide become relevant $[4,21,22]$.
Alkaline-earth metal ions are also present mostly as free cations. They also associate to sulfate or bicarbonate (in a lower extent). Even when they interact with charged anions, their main species is still the free cation, generally representing $\mathrm{ca} .90 \%$ of total concentration. For sample 111 (Table 1) with the highest sulfate concentration, $77 \%$ of calcium and $80 \%$ of magnesium are still free cations. In turn, the predominance of the aqua ions of these abundant elements can markedly influence the speciation of the other elements. Anionic elements form calcium and magnesium bearing species in significant proportions. Taking all samples into account, 6.2-22 \% of Mo is present as ionic pairs with $\mathrm{Ca}$ or $\mathrm{Mg}$. Also for the more abundant S, 4.1-16\% of the element is present as ionic pairs with Ca or Mg. Phosphorous speciation also depends on $\mathrm{pH}$ and the formation of ionic pairs with $\mathrm{Ca}$ or $\mathrm{Mg}$ (Table 2).

Table 2. Most abundant species of selected elements calculated for all samples using Visual MINTEQ software [26] and recent data on trace elements $[23,24,25]^{*}$

\begin{tabular}{|c|c|c|c|c|c|}
\hline Element & Species & $\%$ & Element & Species & $\%$ \\
\hline $\mathrm{Na}(\mathrm{I})$ & $\mathrm{Na}^{+}$ & $98-100$ & $\mathrm{~Pb}(\mathrm{II})$ & $\mathrm{Pb}^{2+}$ & $4.6-37$ \\
\hline $\mathrm{K}(\mathrm{I})$ & $\mathrm{K}^{+}$ & $98-100$ & & {$[\mathrm{~Pb}(\mathrm{OH})]^{+}$} & 1.3-2.9 \\
\hline \multirow[t]{3}{*}{$\mathrm{Mg}(\mathrm{II})$} & $\mathrm{Mg}^{2+}$ & $80-95$ & & {$\left[\mathrm{PbSO}_{4}\right]$} & $0.3-6.6$ \\
\hline & {$\left[\mathrm{MgSO}_{4}\right]$} & 1.6-15 & & {$\left[\mathrm{PbCO}_{3}\right]$} & $16-76$ \\
\hline & {$\left[\mathrm{Mg}\left(\mathrm{HCO}_{3}\right)\right]^{+}$} & $1.3-4.8$ & & {$\left[\mathrm{~Pb}\left(\mathrm{HCO}_{3}\right)\right]^{+}$} & $14-40$ \\
\hline \multirow[t]{3}{*}{$\mathrm{Ca}(\mathrm{II})$} & $\mathrm{Ca}^{2+}$ & $77-94$ & $\mathrm{Fe}(\mathrm{III})$ & {$\left[\mathrm{Fe}(\mathrm{OH})_{2}\right]^{+}$} & $98-100$ \\
\hline & {$\left[\mathrm{CaSO}_{4}\right]$} & $2.0-18$ & $\mathrm{Cl}(-\mathrm{I})$ & $\mathrm{Cl}^{-}$ & $99-100$ \\
\hline & {$\left[\mathrm{Ca}\left(\mathrm{HCO}_{3}\right)\right]^{+}$} & $1.5-5.8$ & C(IV) & $\mathrm{HCO}_{3}{ }^{-}$ & 49-92 \\
\hline \multirow[t]{4}{*}{$\mathrm{Mn}(\mathrm{II})$} & $\mathrm{Mn}^{2+}$ & $72-91$ & & $\mathrm{CO}_{2}(\mathrm{ac})$ & 6.6-50 \\
\hline & {$\left[\mathrm{MnSO}_{4}\right]$} & $1.3-13$ & & {$\left[\mathrm{Ca}\left(\mathrm{HCO}_{3}\right)\right]^{+}$} & $0.2-1.3$ \\
\hline & {$\left[\mathrm{Mn}\left(\mathrm{HCO}_{3}\right)\right]^{+}$} & $2.5-7.5$ & $\mathrm{~S}(\mathrm{VI})$ & $\mathrm{SO}_{4}{ }^{2-}$ & $81-93$ \\
\hline & {$\left[\mathrm{MnCO}_{3}\right]$} & $0.6-18$ & & {$\left[\mathrm{MgSO}_{4}\right]$} & $1.4-4.8$ \\
\hline \multirow[t]{4}{*}{$\mathrm{Co}(\mathrm{II})$} & $\mathrm{Co}^{2+}$ & 66-86 & & {$\left[\mathrm{CaSO}_{4}\right]$} & $3.2-13$ \\
\hline & {$\left[\mathrm{CoSO}_{4}\right]$} & $1.4-14$ & & {$\left[\mathrm{NaSO}_{4}\right]^{-}$} & $0.9-2.9$ \\
\hline & {$\left[\mathrm{Co}\left(\mathrm{HCO}_{3}\right)\right]^{+}$} & $8.3-26$ & $\mathrm{P}(\mathrm{V})$ & $\mathrm{HPO}_{4}{ }^{2-}$ & $15-57$ \\
\hline & {$\left[\mathrm{CoCO}_{3}\right]$} & $0.2-6.5$ & & $\mathrm{H}_{2} \mathrm{PO}_{4}^{-}$ & $22-81$ \\
\hline \multirow[t]{4}{*}{$\mathrm{Ni}(\mathrm{II})$} & $\mathrm{Ni}^{2+}$ & 56-81 & & {$\left[\mathrm{MgHPO}_{4}\right]$} & $1.0-9.3$ \\
\hline & {$\left[\mathrm{NiSO}_{4}\right]$} & $1.2-12$ & & {$\left[\mathrm{CaHPO}_{4}\right]$} & 1.4-13 \\
\hline & {$\left[\mathrm{NiCO}_{3}\right]$} & $0.4-11$ & & {$\left[\mathrm{NaHPO}_{4}\right]^{-}$} & $0.5-3.2$ \\
\hline & {$\left[\mathrm{Ni}\left(\mathrm{HCO}_{3}\right)\right]^{+}$} & $0.6-34$ & $\mathrm{Mo}(\mathrm{VI})$ & $\mathrm{MoO}_{4}{ }^{2-}$ & 78-93 \\
\hline \multirow[t]{5}{*}{$\mathrm{Cu}(\mathrm{II})$} & $\mathrm{Cu}^{2+}$ & $3.2-50$ & & $\mathrm{HMoO}_{4}^{-}$ & $0.1-0.4$ \\
\hline & {$[\mathrm{Cu}(\mathrm{OH})]^{+}$} & $1.5-3.0$ & & {$\left[\mathrm{MgMoO}_{4}\right]$} & $0.6-1.9$ \\
\hline & {$\left[\mathrm{CuSO}_{4}\right]$} & $0.1-3.8$ & & {$\left[\mathrm{CaMoO}_{4}\right]$} & $5.6-20$ \\
\hline & {$\left[\mathrm{CuCO}_{3}\right]$} & $37-91$ & $\mathrm{Se}(\mathrm{VI})$ & $\mathrm{SeO}_{4}^{2-}$ & 94-98 \\
\hline & {$\left[\mathrm{Cu}\left(\mathrm{HCO}_{3}\right)\right]^{+}$} & $0.8-4.1$ & & {$\left[\mathrm{CaSeO}_{4}\right]$} & $1.6-6.5$ \\
\hline \multirow[t]{4}{*}{$\mathrm{Zn}(\mathrm{II})$} & $\mathrm{Zn}^{2+}$ & $67-89$ & $\mathrm{As}(\mathrm{V})$ & $\mathrm{HAsO}_{4}{ }^{2-}$ & $23-80$ \\
\hline & {$\left[\mathrm{ZnSO}_{4}\right]$} & $1.5-5.0$ & & $\mathrm{H}_{2} \mathrm{AsO}_{4}^{-}$ & $20-77$ \\
\hline & {$\left[\mathrm{ZnCO}_{3}\right]$} & $0.6-19$ & $\mathrm{~V}(\mathrm{~V})$ & $\mathrm{H}_{2} \mathrm{VO}_{4}^{-}$ & $94-100$ \\
\hline & {$\left[\mathrm{Zn}\left(\mathrm{HCO}_{3}\right)\right]^{+}$} & 3.5-11 & & $\mathrm{HVO}_{4}{ }^{2-}$ & $0.5-6.5$ \\
\hline \multirow[t]{4}{*}{ Cd(II) } & $\mathrm{Cd}^{2+}$ & 53-87 & & & \\
\hline & {$\left[\mathrm{CdSO}_{4}\right]$} & $1.6-25$ & & & \\
\hline & {$\left[\mathrm{CdCO}_{3}\right]$} & $0.2-8.8$ & & & \\
\hline & {$\left[\mathrm{Cd}\left(\mathrm{HCO}_{3}\right)\right]^{+}$} & $3.2-12$ & & & \\
\hline
\end{tabular}

"Oxygen saturation was assumed in calculation

Alkaline-earth cations provide also a good example on the influence of the concentration in speciation. Sr and $\mathrm{Ba}$ have a very similar chemical behavior to $\mathrm{Ca}$ or $\mathrm{Mg}$, but they are far less abundant. So, they will have a less marked influence on the speciation of the present anions. All alkaline-earth cations associate in solution to form sulfate ionic pairs with similar low formation constants (for example, $\log K\left(\mathrm{CaSO}_{4}\right)=2.35$ [28]; $\log K\left(\mathrm{BaSO}_{4}\right)=$ 2.49 [29]). For equimolar concentrations of both cations, similar percentages of the ionic pairs are expected to be formed with sulfate anion. But in the concentration range observed in the natural waters, the most abundant calcium 
retains a higher percentage of sulfate anion, whereas barium ionic pair is not relevant in sulfur speciation. Notwithstanding, the free Ca percentage is still high, even higher than that for Ba. This is shown in Figure 2 where calcium, barium and sulfate concentrations of sample 111 were used.
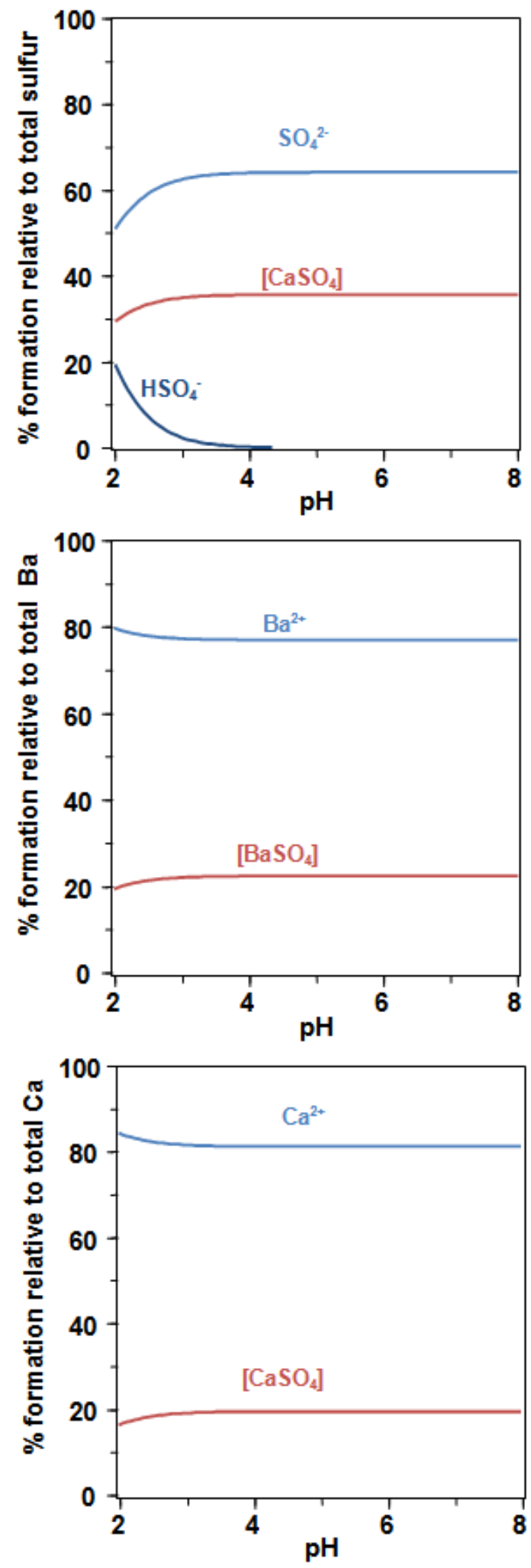

Figure 2. Speciation calculation results for calcium, barium and sulfate concentrations of sample 111. HySS software [27] and previously reported data [21] were used

Interestingly, for this and many other samples, precipitation of barium sulfate is expected if we consider total barium and sulfate concentrations. Despite the presence of other cations as calcium, magnesium and strontium interacting with sulfate are probably retaining the anion in solution. This fact, observed also in many samples for basic calcium phosphate (hydroxyapatite), can affect the mobility of the elements in the hydrogeological cycle.

\subsection{Speciation of Trace Elements}

The chemical behavior of trace elements forming cations is clearly different to those forming anions [21,22]. The analysis of reactivity and mobility of trace elements indicates that cationic trace elements tend to be strongly retained by the earth's crust owing to ion exchange, sorption and mineral precipitation. They do not accumulate in groundwater to very high concentration levels. In contrast, anionic trace elements (mainly oxyanions), although retained by earth materials (clays and sesquioxides) to some extent, are subject to greater mobility. They may have high localized concentrations in groundwater [30], mostly caused by human activities. In addition, both cations and anions may associate in solution with other inorganic or organic species, attaining greater mobility by forming soluble compounds. Temperature, $\mathrm{pH}$, and redox state are also important to determine this behavior.

Metal cations of $d$ and $p$ blocks appear partially as soluble ionic pairs with sulfate, bicarbonate or even carbonate (see Table 2). For higher $\mathrm{pH}$ values, the deprotonation of bicarbonate gives carbonate which is more charged and consequently interacts more strongly with cations. The proportion of ionic pairs formed with carbonate is higher for copper and lead, i.e. those cations with higher affinity for that anion. For example, at $25^{\circ} \mathrm{C}$, $\log K_{1}$ for the formation of $\left[\mathrm{MCO}_{3}\right]$ are $4.44(\mathrm{Ca}), 4.83$ $(\mathrm{Ni}), 4.75(\mathrm{Zn}), 6.75(\mathrm{Cu})$ and $6.45(\mathrm{~Pb})$ [21]. Figure 3 shows the predominance of copper species including copper carbonate ionic pairs as a function of $\mathrm{pH}$ for all studied samples. Bicarbonate ionic pair is not a predominant species even though bicarbonate in the absence of metal ions is expected to deprotonate giving place to carbonate above $\mathrm{pH} 9$.

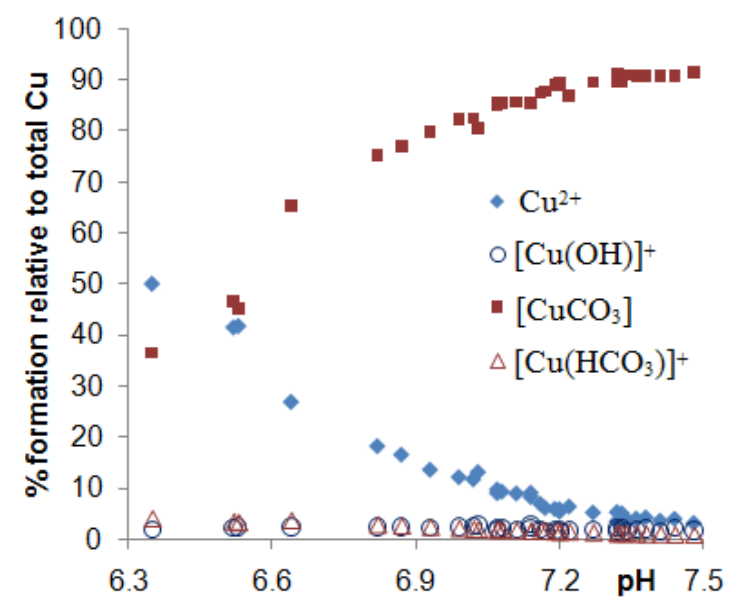

Figure 3. Predominance of copper carbonate ionic pair calculated for all samples as a function of $\mathrm{pH}$

We will discuss the speciation of the trace elements forming anions taking two different examples of essential elements for which we have measured all necessary 
stability constants of the interaction with metal cations: molybdenum and selenium. Molybdenum is a metal and selenium is a non-metal. Both of them form anionic species in their high oxidation states present in most natural waters. They are naturally occurring trace elements, essential to life but toxic at high concentrations. Their relevance to the environment has been only recently recognized [2,7]. The predominant anionic species are markedly affected by the presence of +2 major cations. Molybdenum in the aquatic environment forms oxo/hydroxo species in oxidation state +6 including polyanions $[4,21,22,31]$. The predominant species at $\mathrm{pH}$ $5-6$ or above is the molybdate anion, $\mathrm{MoO}_{4}{ }^{2-}$. For more acidic $\mathrm{pH}$ values, molybdate becomes protonated, giving place to the less charged anionic species, $\mathrm{HMoO}_{4}{ }^{-}$. Selenium also forms oxo species in oxidation state +6 , mostly selenate, $\mathrm{SeO}_{4}{ }^{2-}$. It remains deprotonated in the $\mathrm{pH}$ range of natural waters and its interaction with metal cations is weaker than that observed for Mo [21,22,23,24].

Taking into account the measured data of the Raigón aquifer system and all the measured interactions for molybdate, sulfate and bicarbonate/carbonate with all present cations, the predominant species can be calculated. Figure 4 shows some selected results for samples 4 and 111 (Table 1). It can be seen that water hardness, related to calcium and magnesium concentrations, is a very relevant parameter in determining the formed species. The influence of alkaline-earth metal ions is clear. It can be highlighted by calculating the speciation under the same conditions of sample 4 but changing the water hardness 10 times (Figure 4).

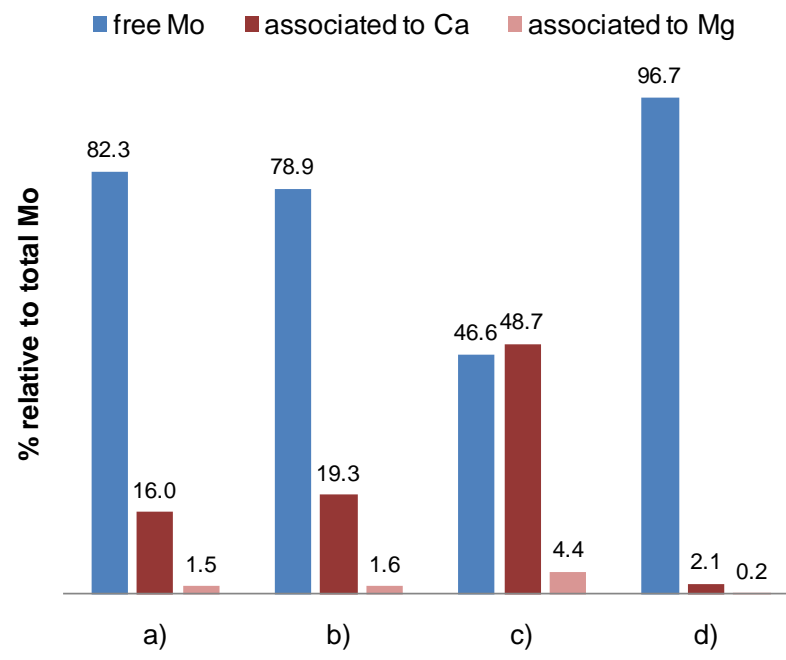

Figure 4. Speciation results for samples 4 and 111. a) sample 4, b) sample 111, c) sample 4 with $\mathrm{Ca}$ and $\mathrm{Mg} 10$ times higher, d) sample 4 with $\mathrm{Ca}$ and $\mathrm{Mg} 10$ times lower. Low percentages of $\left[\mathrm{SrMoO}_{4}\right]$ and $\left[\mathrm{BaMoO}_{4}\right]$ are also present

If we compare these results with those obtained by Visual MINTEQ 3.1 [26], but using only the stability constants included in the original database, similar general results are obtained. In the case of Mo, the predominant form is still the molybdate anion and associations with alkaline-earth metal ions are also operative. The relative portions associated with $\mathrm{Ca}$ or $\mathrm{Mg}$ are slightly different. This is due to the fact that Visual MINTEQ database uses for $\left[\mathrm{MgMoO}_{4}\right]$ and $\left[\mathrm{CaMoO}_{4}\right]$, the formation constants reported by [32]. In this report, molybdate association with $\mathrm{Mg}$ is 10 times stronger compared to the analogous interaction with Ca. However, our previous data show that both alkaline earth metal ions behave similarly towards the anion [25], in line with previous reports on alkalineearth interactions with anions. The formation (even in low percentages) of other ionic pairs $\left[\mathrm{MMoO}_{4}\right]$ for some $3 d$ metal ions is not observed when new thermodynamic data are included. The difference originates in the fact that these species are not included in the Visual MINTEQ database.

Table 3. Predominant species calculated for samples 125 and 57 using Visual MINTEQ program, its database [26] and data from $[23,24,25]$. Redox equilibria are included, set $\mathrm{p} E$ are indicated

\begin{tabular}{|c|c|c|c|c|c|}
\hline \multicolumn{3}{|c|}{ Sample 125, pE 14} & \multicolumn{3}{|c|}{ Sample 57, pE 4} \\
\hline Element & $\%$ & Species & Element & $\%$ & Species \\
\hline \multirow[t]{3}{*}{$\mathrm{Mg}$} & 93.2 & $\mathrm{Mg}^{2+}$ & $\mathrm{Mg}$ & 83.2 & $\mathrm{Mg}^{2+}$ \\
\hline & 3.9 & {$\left[\mathrm{MgSO}_{4}\right]$} & & 11.6 & {$\left[\mathrm{MgSO}_{4}\right]$} \\
\hline & 2.3 & {$\left[\mathrm{MgHCO}_{3}\right]^{+}$} & & 3.7 & {$\left[\mathrm{MgHCO}_{3}\right]^{+}$} \\
\hline \multirow[t]{3}{*}{$\mathrm{Ca}$} & 92.0 & $\mathrm{Ca}^{2+}$ & $\mathrm{Ca}$ & 80.6 & $\mathrm{Ca}^{2+}$ \\
\hline & 4.8 & {$\left[\mathrm{CaSO}_{4}\right]$} & & 14.1 & {$\left[\mathrm{CaSO}_{4}\right]$} \\
\hline & 2.7 & {$\left[\mathrm{CaHCO}_{3}\right]^{+}$} & & 4.3 & {$\left[\mathrm{CaHCO}_{3}\right]^{+}$} \\
\hline \multirow[t]{3}{*}{$\mathrm{Sr}$} & 92.4 & $\mathrm{Sr}^{2+}$ & $\mathrm{Sr}$ & 81.9 & $\mathrm{Sr}^{2+}$ \\
\hline & 4.2 & {$\left[\mathrm{SrSO}_{4}\right]$} & & 12.4 & {$\left[\mathrm{SrSO}_{4}\right]$} \\
\hline & 3.2 & {$\left[\mathrm{SrHCO}_{3}\right]^{+}$} & & 5.1 & {$\left[\mathrm{SrHCO}_{3}\right]^{+}$} \\
\hline \multirow[t]{3}{*}{$\mathrm{Ba}$} & 94.9 & $\mathrm{Ba}^{2+}$ & $\mathrm{Ba}$ & 87.0 & $\mathrm{Ba}^{2+}$ \\
\hline & 3.0 & {$\left[\mathrm{BaSO}_{4}\right]$} & & 9.3 & {$\left[\mathrm{BaSO}_{4}\right]$} \\
\hline & 2.0 & {$\left[\mathrm{BaHCO}_{3}\right]^{+}$} & & 3.2 & {$\left[\mathrm{BaHCO}_{3}\right]^{+}$} \\
\hline \multirow[t]{3}{*}{$\mathrm{Mn}$} & 87.1 & $\mathrm{Mn}^{2+}$ & Mn & 74.2 & $\mathrm{Mn}^{2+}$ \\
\hline & 4.2 & {$\left[\mathrm{MnHCO}_{3}\right]^{+}$} & & 6.4 & {$\left[\mathrm{MnHCO}_{3}\right]^{+}$} \\
\hline & 4.5 & {$\left[\mathrm{MnCO}_{3}\right]$} & & 9.0 & {$\left[\mathrm{MnCO}_{3}\right]$} \\
\hline \multirow[t]{4}{*}{$\mathrm{Fe}$} & 0 & $\mathrm{Fe}^{2+}$ & $\mathrm{Fe}$ & 72.0 & $\mathrm{Fe}^{2+}$ \\
\hline & 0 & {$\left[\mathrm{FeSO}_{4}\right]$} & & 13.4 & {$\left[\mathrm{FeSO}_{4}\right]$} \\
\hline & 99.4 & {$\left[\mathrm{Fe}(\mathrm{OH})_{2}\right]^{+}$} & & 10.3 & {$\left[\mathrm{Fe}(\mathrm{OH})_{2}\right]^{+}$} \\
\hline & 0.4 & {$\left[\mathrm{Fe}(\mathrm{OH})_{3}\right]$} & & 0 & {$\left[\mathrm{Fe}(\mathrm{OH})_{3}\right]$} \\
\hline \multirow[t]{3}{*}{ Co } & 80.2 & $\mathrm{Co}^{2+}$ & Co & 65.8 & $\mathrm{Co}^{2+}$ \\
\hline & 1.6 & {$\left[\mathrm{CoCO}_{3}\right]$} & & 3.0 & {$\left[\mathrm{CoCO}_{3}\right]$} \\
\hline & 14.9 & {$\left[\mathrm{CoHCO}_{3}\right]^{+}$} & & 20.9 & {$\left[\mathrm{CoHCO}_{3}\right]^{+}$} \\
\hline \multirow[t]{3}{*}{$\mathrm{Ni}$} & 73.2 & $\mathrm{Ni}^{2+}$ & $\mathrm{Ni}$ & 57.1 & $\mathrm{Ni}^{2+}$ \\
\hline & 2.8 & {$\left[\mathrm{NiCO}_{3}\right]$} & & 5.2 & {$\left[\mathrm{NiCO}_{3}\right]$} \\
\hline & 20.4 & {$\left[\mathrm{NiHCO}_{3}\right]^{+}$} & & 28.8 & {$\left[\mathrm{NiHCO}_{3}\right]^{+}$} \\
\hline \multirow[t]{4}{*}{$\mathrm{Cu}$} & 13.2 & $\mathrm{Cu}^{2+}$ & $\mathrm{Cu}$ & 5.9 & $\mathrm{Cu}^{2+}$ \\
\hline & 2.8 & {$[\mathrm{CuOH}]^{+}$} & & 1.4 & {$[\mathrm{CuOH}]^{+}$} \\
\hline & 80.4 & {$\left[\mathrm{CuCO}_{3}\right]$} & & 84.9 & {$\left[\mathrm{CuCO}_{3}\right]$} \\
\hline & 0 & {$[\mathrm{CuCl}]$} & & 1.4 & [CuCl] \\
\hline \multirow[t]{3}{*}{$\mathrm{Zn}$} & 83.6 & $\mathrm{Zn}^{2+}$ & $\mathrm{Zn}$ & 68.5 & $\mathrm{Zn}^{2+}$ \\
\hline & 5.0 & {$\left[\mathrm{ZnCO}_{3}\right]$} & & 9.6 & {$\left[\mathrm{ZnCO}_{3}\right]$} \\
\hline & 6.0 & {$\left[\mathrm{ZnHCO}_{3}\right]^{+}$} & & 8.9 & {$\left[\mathrm{ZnHCO}_{3}\right]^{+}$} \\
\hline \multirow[t]{3}{*}{$\mathrm{S}$} & 89.6 & $\mathrm{SO}_{4}{ }^{2-}$ & $\mathrm{S}$ & 82.8 & $\mathrm{SO}_{4}^{2-}$ \\
\hline & 2.6 & {$\left[\mathrm{MgSO}_{4}\right]$} & & 4.2 & {$\left[\mathrm{MgSO}_{4}\right]$} \\
\hline & 6.4 & {$\left[\mathrm{CaSO}_{4}\right]$} & & 9.9 & {$\left[\mathrm{CaSO}_{4}\right]$} \\
\hline \multirow[t]{5}{*}{ Se } & 96.8 & $\mathrm{SeO}_{4}{ }^{2-}$ & Se & 0 & $\mathrm{SeO}_{4}{ }^{2-}$ \\
\hline & 3.2 & {$\left[\mathrm{CaSeO}_{4}\right]$} & & 0 & {$\left[\mathrm{CaSeO}_{4}\right]$} \\
\hline & 0 & $\mathrm{HSeO}_{3}^{-}$ & & 5.7 & $\mathrm{HSeO}_{3}^{-}$ \\
\hline & 0 & {$\left[\mathrm{CaHSeO}_{3}\right]^{+}$} & & 74.9 & {$\left[\mathrm{CaHSeO}_{3}\right]^{+}$} \\
\hline & 0 & {$\left[\mathrm{MgHSeO}_{3}\right]^{+}$} & & 19.2 & {$\left[\mathrm{MgHSeO}_{3}\right]$} \\
\hline \multirow[t]{4}{*}{$\mathrm{P}$} & 41.1 & $\mathrm{HPO}_{4}{ }^{2-}$ & $\mathrm{P}$ & 45.4 & $\mathrm{HPO}_{4}{ }^{2-}$ \\
\hline & 47.0 & $\mathrm{H}_{2} \mathrm{PO}_{4}^{-}$ & & 31.4 & $\mathrm{H}_{2} \mathrm{PO}_{4}^{-}$ \\
\hline & 4.0 & {$\left[\mathrm{MgHPO}_{4}\right]$} & & 7.8 & {$\left[\mathrm{MgHPO}_{4}\right]$} \\
\hline & 5.7 & {$\left[\mathrm{CaHPO}_{4}\right]$} & & 10.5 & {$\left[\mathrm{CaHPO}_{4}\right]$} \\
\hline \multirow[t]{3}{*}{ Mo } & 87.9 & $\mathrm{MoO}_{4}{ }^{2-}$ & Mo & 81.4 & $\mathrm{MoO}_{4}^{2-}$ \\
\hline & 10.9 & {$\left[\mathrm{CaMoO}_{4}\right]$} & & 16.8 & {$\left[\mathrm{CaMoO}_{4}\right]$} \\
\hline & 1.0 & {$\left[\mathrm{MgMoO}_{4}\right]$} & & 1.7 & {$\left[\mathrm{MgMoO}_{4}\right]$} \\
\hline
\end{tabular}

The $\mathrm{pH}$ is also a relevant parameter for molybdenum speciation. Speciation calculation yields very similar results in the $\mathrm{pH}$ range 6-8. The situation changes for 
lower $\mathrm{pH}$ values. This could be the situation for example if the acid employed for metal mines exploitation in the area is incorporated into water reservoir causing localized imbalances of mineral acidity. At $\mathrm{pH} 4$, molybdate anion is partially protonated and not associated with cations, changing the speciation. The less charged $\mathrm{HMoO}_{4}$ interacts with metal cations to a lesser extent as shown in Figure 5 for sample 4 . These results are relevant to consider molybdenum environmental chemistry: the element is highly mobile in alkaline soils and subjected to leaching from rainfall and irrigation. Plant uptake of Mo is greater in alkaline than acid soils. In general, an increase of $\mathrm{pH}$ increases Mo solubility [33].

\section{3. $\mathrm{p} E$ Influence}

Speciation of some trace elements can be also influenced significantly by redox potential. To exemplify this, we can again focus on Mo and Se. In the case of Mo, the high stability of +6 oxidation state $\left(E^{\circ} \mathrm{MoO}_{4}{ }^{2-} / \mathrm{MoO}_{2}\right.$ $=0.89 \mathrm{~V}$ ) implies that no changes are observed when changing $\mathrm{p} E$ values. Instead, oxidation states of Se in soils and weathering sediments are influenced by both $\mathrm{p} E$ and $\mathrm{pH}$.

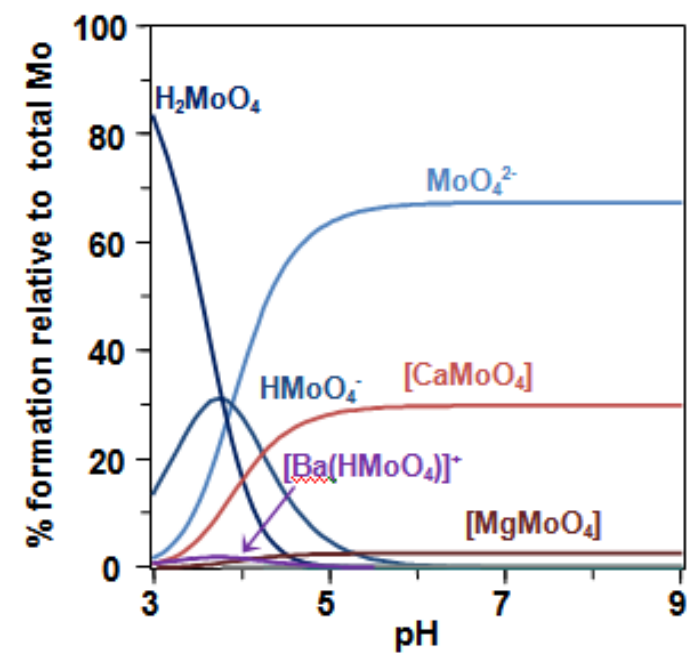

Figure 5. Speciation of Mo. Influence of $\mathrm{pH}$ value. Calculated by HySS program [27] using sample 4 concentrations and previously reported data $[21,23,24,25]$

The presence of cations certainly will further modify the chemistry of these species. We can compare the results of samples taken at different oxygen concentrations, to study selenium speciation. Regarding sample 125 (Table 1), an oxygen saturated environment is applicable (6 m depth). Due to oxic conditions, most elements are in their highest oxidation state. Some selected results for this sample are shown in Table 3. If we consider sample 57 (Table 1), of $45 \mathrm{~m}$ depth, with a much lower $\mathrm{p} E$, the present species are different (Table 3) only for some elements. As previously discussed, the situation of the most abundant ions does not change. Slight differences between these two samples arise from the variation in $\mathrm{pH}$ and sulfate concentration, both values higher for sample 57 (Table 1). Speciation markedly changes only for some elements like iron or selenium, which have accessible lower oxidation states for low $\mathrm{p} E$ values. In the case of selenium, $\mathrm{p} E$ values (related to depth of the groundwater well) is also a major parameter that determines the predominant form. Selenate ion, $\mathrm{SeO}_{4}{ }^{2-}$, gives place to $\mathrm{HSeO}_{3}^{-}$, which is highly associated with alkaline-earth metal ions. This result is of the utmost importance when considering the mobility, availability and fate of Se. Soils have a stronger trend to sorb selenite as compared to selenate, being strongly bound to Fe2O3-like solids. On the contrary, the leaching of Se in soils is more likely to be enhanced under oxic alkaline conditions where the predominant form is selenate [32].

\section{Conclusions}

Thermodynamic information in combination with experimental analytical data on concentration levels of chemical elements and some physicochemical parameters proved to be useful to get a deeper understanding of aquatic systems. This was accomplished by generation of a complete chemical model that allows studying the aquatic system using concentration of chemical species of elements instead of total concentration data.

Taking experimental data from the Raigón aquifer, chemical modeling using Visual MINTEQ program, shows that most abundant elements maintain the same predominant species in almost all physicochemical conditions. For trace elements speciation is quite dependant on localized changes in the aquatic scenarios and also on the concentration values of major elements. This tool is very useful to study the speciation of specific trace elements, and to simulate their chemical behavior in cases of environment changes.

The chemical model generated was applied to Mo and Se trace elements. Both form anionic species, predominantly $\mathrm{MoO}_{4}{ }^{2-}$ and $\mathrm{SeO}_{4}{ }^{2-}$. These anions interact in solution and are greatly influenced by the concentration of the abundant calcium ion. Localized changes in $\mathrm{pH}$ can strongly affect the situation. The same is observed with the $\mathrm{p} E$ parameter, but only in the case of Se.

\section{Acknowledgement}

The authors are grateful to CSIC (Programa de Apoyo a Grupos) and ANII (Project FCE_2011_6491), Uruguayan organizations, for financial support.

\section{References}

[1] J. Bossi, Geología del Uruguay, Departamento de Publicaciones, Universidad de la República, Montevideo, 1966.

[2] A. Manganelli, C. Goso, R. Guerequiz, J. L. Fernández Turiel, M. García-Vallés, D. Gimeno, C. Pérez, "Groundwater arsenic distribution in South-western Uruguay”, Environmental Geology 53, 827-834, March 2007.

[3] N. Mañay, "Developing Medical Geology in Uruguay: A Review”, International Journal of Environmental Research Public Health, 7 , 1963-1969, April 2010.

[4] I. Bodek, W. J. Lyman, W. F. Feehl, D. H. Rosenblatt, Environmental Inorganic Chemistry, Pergamon Press, New York, 1988.

[5] H. D. Holland, K.K. Turekian (Executive Editors), Treatise on Geochemistry, Elsevier Ltd., 2003, Volume 5, section 5.04.

[6] P.A. Cox, The Elements on Earth: Inorganic Chemistry in the Envrironment, Oxford University Press, Oxford, 1995.

[7] C. T. Avellán, D. Rousseau, P. Lens, "Community based approach towards water quality restoration and pollution prevention of the Flores Creeek (Uruguay)" in Integrated water resources 
management Karlsruhe 2010, KIT Scientific Publishing, section 2.3 .

[8] N. Mañay, N, C. Goso, M. Pistón, J. L. Fernández-Turiel, M. García-Vallés, M. Rejas, R. Guerequiz, “Groundwater arsenic content in Raigón aquifer system (San José, Uruguay)”, Revista. de la Sociedad Uruguaya de Geología, 18, 20-38, November 2013.

[9] M. I. Bellini, L. Gutiérrez, S. Tarlera, A. Fernández Scavino, "Isolation and functional analysis of denitrifiers in an aquifer with high potential for denitrification”, Systematic and Applied Microbiology, 36, 505-516, August 2013.

[10] W. Stumm, J. J. Morgan, Aquatic Chemistry: Chemical Equilibria and Rates in Natural Waters, $3^{\text {rd }}$ ed., Wiley, Pasadena, 1996.

[11] H. D. Holland, K.K. Turekian (Executive Editors), Treatise on Geochemistry, Elsevier Ltd., 2003, Volume 5, section 5.09.

[12] W. M. Edmunds, “Geochemistry's vital contribution to solving water resource problems”, Applied Geochemistry, 24, 1058-1073, February 2009.

[13] O. Selinus (Chief Editor), Essentials of Medical Geology, Elsevier, Burlington, 2005.

[14] Z. L. He, X. E. Yang, P. J. Stoffella, "Trace elements in agroecosystems and impacts on the environment”, Journal of Trace Elements in Medicine and Biology, 19, 125-140, February 2005.

[15] J. E. Groenenberg, S. Lofts, "The use of assemblage models to describe trace elements partitioning, speciation and fate: a review" Environmental Toxicology and Chemistry, 33, 2181-2196, May 2014.

[16] P. M. May, "JESS at thirty: Strengths, weaknesses and future needs in the modeling of chemical speciation”, Applied Geochemistry 55, 3-16, January 2015.

[17] M. Filella. P. M. May, "Computer simulation of the lowmolecular-weight inorganic species distribution of antimony (III) and antimony(V) in natural waters" Geochimica et Cosmochimica Acta, 67, 4013-4031, January 2003

[18] T. Cheng, K. De Schamphelaere, S. Lofts, C. Janssen, H. E. Allen, "Measurement and computation of zinc binding to natural dissolved organic matter in European surface waters" Analitica Chimica Acta, 542, 230-239, April 2005.

[19] E. Tipping E, H. T. Carter, "Aluminium speciation in streams and lakes of the UK Acid Waters Monitoring Network, modelled with WHAM", Science of the Total Environment 409, 1550-1558, February 2011.

[20] J. B. Christensen, J. J. Botma, T. H. Christensen, “Complexation of $\mathrm{Cu}$ and $\mathrm{Pb}$ by $\mathrm{DOC}$ in polluted groundwater: A comparison of experimental data and predictions by computer speciation models
(WHAM and MINTEQA2)”, Water Res 33, 3231-3238, January 1999.

[21] Stability Constants Database, IUPAC 2007.

[22] P. M. May, K. Murray, “JESS - a Joint Expert Speciation System”, Talanta 38, 1409-1417, June 1991.

[23] J. Torres, V. Pintos, S. Domínguez, C. Kremer, E. Kremer, "Selenite and Selenate Speciation in Natural Waters: Interaction with Divalent Metal Ions”, Journal of Solution Chemistry, 39, 110, January 2010.

[24] J. Torres, V. Pintos, L. Gonzatto, S. Domínguez, C. Kremer, E. Kremer, "Selenium chemical speciation in natural waters: Protonation and complexation behavior of selenite and selenate in the presence of environmentally relevant cations", Chemical Geology, 288, 32-38, July 2011.

[25] J. Torres, L. Gonzatto, G. Peinado, C. Kremer, E. Kremer, "Interaction of Molybdenum(VI) Oxyanions with +2 Metal Cations”, Journal of Solution Chemistry, 43, 1687-1700, October 2014

[26] Visual MINTEQ ver. 3.1 (released 2014) J. P. Gustafsson

[27] L. Alderighi, P. Gans, A. Ienco, D. Peters, A. Sabatini. A. Vacca., "Hyperquad simulation and speciation (HySS): a utility program for the investigation of equilibria involving soluble and partially soluble species”, Coordination Chemistry Reviews, 184, 311-318, 1999.

[28] K. Raju, G. Atkinson, "The thermodynamics of "scale” mineral solubilities. 3. Calcium sulfate in aqueous NaCl”, Journal of Chemical and Engeneering Data, 35, 361-367, 1990.

[29] C. Paige, W. Kornicker, O. Hileman, "Solution equilibria for uranium ore processing: The $\mathrm{BaSO}_{4}-\mathrm{H}_{2} \mathrm{SO}_{4}-\mathrm{H}_{2} \mathrm{O}$ system and the $\mathrm{BaSO}_{4}-\mathrm{H}_{2} \mathrm{SO}_{4}-\mathrm{H}_{2} \mathrm{O}$ system”, Geochimica et Cosmochimica Acta, 62, 15-23, 1998.

[30] K. Tanji, L. Valoppi, "Groundwater Contamination by Trace Elements”, Agriculture, Ecosystems and Environment, 26, 229274, June 1989.

[31] J. J. Cruywagen, A. G. Draaijer, J. B. B. Heyns, E. A. Rohwer, "Molybdenum(VI) equilibria in different ionic media. Formation constants and thermodynamic quantities”, Inorganica Chimica Acta, 331, 322-329, January 2002.

[32] M. E. Essington, "Formation of calcium and magnesium molybdate complexes un dilute aqueous solutions", Soil Science Society of America Journal, 56, 1124-1127, July 1992. 